\title{
Design and Initial Validation of the Scales Epistemology, Methodology and Gender in Taught History (EMG), and Women in History (WH) for the Evaluation of Gender Competence of Social Science Teachers in Training
}

\author{
Delfín Ortega-Sánchez ${ }^{1, *}$, Davinia Heras Sevilla ${ }^{2}$ \\ ${ }^{1}$ Department of Specific Didactics, Faculty of Education, University of Burgos, Spain \\ ${ }^{2}$ Department of Educational Sciences, Faculty of Education, University of Burgos, Spain \\ Received February 2, 2020; Revised March 23, 2020; Accepted March 28, 2020
}

Copyright $(2020$ by authors, all rights reserved. Authors agree that this article remains permanently open access under the terms of the Creative Commons Attribution License 4.0 International License

\begin{abstract}
In recent decades, it has been frequent to apply instruments and built ad hoc in studies oriented to the diagnostic evaluation of the inclusion of the gender perspective in the teaching of history and the degree of acquisition of gender competence in the initial teaching training. However, less usual has been the work dedicated to the analysis and validation of the metric properties of these instruments, with the specific purpose of guaranteeing the validity of the conclusions reached from the data obtained. In order to respond to this absence, the present study describes the initial validation of the scales Epistemology, methodology and gender in taught history (EMG) and Women in history (WH) in a sample of primary and secondary school trainee teachers from four Spanish public universities. With this aim, the reliability of each scale, the validity of its content and the construct validity are studied by means of an exploratory factorial analysis of principal components and varimax rotation. The results obtained inform about the general viability of both scales to be applied for the evaluation of the gender competence of trainee teachers, and the analysis of their social representations on the place of women in the taught history. The study shows the functional interdependence between scales and robustness for its joint application in the general assessment of gender as a category of analysis in social science teaching.
\end{abstract}

Keywords Reliability, Internal Consistency, Factor Structure, Gender, History Teaching

\section{Introduction}

The inclusion of the gender perspective and its strategic mainstreaming for equality (gender mainstreaming) in the teaching of history is one of the most recognized teaching and research concerns in the scientific field of social science teaching. This perspective, understood as a conceptual and methodological framework for the analysis of the causes and consequences of biases, inequalities and social differentiation based on sex, considers stereotyping, prejudice and the allocation of social roles in the deconstruction of "desirable gender models" [1], which are determining factors in the hegemonic duality of identity, and are directed towards the recognition of social plurality as a principle for the formation of multiple and diverse gender identities [2].

The incorporation of gender as a category of analysis in the teaching of the social sciences $[3,4]$ makes it possible to recognize the operability of gender stereotypes in social relations and patterns of behaviour, channelled into discourses and teaching practices. In this sense, the school is presented as a priority center for the transmission of codes, imaginaries, and social rules that determine the ways of thinking and of being thought of in the society in which one lives. The educational inclusion of this perspective moves away from the traditional heteronormity of sex and gender, and from the socializing reproduction of social and cultural references that seek to explain a certain society, in order to inform in order to form, train in order to raise awareness and commit to the eradication of gender inequalities [5].

The uncritical maintenance of the androcentric bases in the history taught consolidates the invisibility of women as social agents, and the unequal hegemony of dichotomous social and identity values and models [6]. These deterministic bases of the social prevent an integral and plural understanding of historical societies and of the way in which social knowledge and its relativity are constructed, 
which is often absent in the textual and iconographic narrative discourses of textbooks and teaching materials $[5,7,8]$.

There is little very recent research focused on the study of social representations and the effectiveness of teacher training programmes on the inclusion of gender as a category of analysis in the teaching of history, both in the field of teacher training [6,9-11] and of in-service teachers [12]. From the principles of education for global citizenship, the inclusion of this socially and historically determined concept should promote the visibility of women, and avoid the reproduction of androcentric structures in the training of history and social science teachers, which is still weak in programmes and teaching practices [13].

Despite the activity of institutional commissions, units or observatories, and the efforts to incorporate the gender perspective in the various stages of education [6, 14-16], the resistance of the university institution to incorporating specific subjects designed from a gender perspective into its curricula seems to be confirmed. These limitations result in the professionalization of students without the necessary theoretical and practical instruments in the area of gender to develop their own programs $[9,17]$.

In this context, this research aims to describe the first phase of validation of the scales Epistemology, methodology and gender in taught history (EMG), and Women in history (WH) and to analyze their interdependence. Both scales are aimed at the analysis of the social representations of teachers in training on the relevance of gender mainstreaming in the teaching and learning of history, and the consideration of the concept of gender as a category of analysis in the teaching of social sciences. Understanding the age and the hours of training in gender, coeducation and education for equality received by students as conditioning factors of their social representations and their knowledge about women in history, in a complementary way, the research analyzes the possible dependency relations between these study variables.

\section{Method}

\subsection{Participants}

The participating sample was composed of a total of 22 women (66.7\%) and 11 men (33.3\%), with an average age of 30.06 years $(\mathrm{SD}=10.69)$, enrolled in the Bachelor's Degree in Primary Education (18.2\%), in the Master's Degree in Secondary Education (78.8\%), and in other official studies (3\%), from four Spanish public universities and other institutions: University of Burgos (75.8\%), University of Murcia (15.2\%), University of Valladolid (3\%), University of Alicante (3\%) and other institutions (3\%). The sampling was non-probabilistic for convenience [18], according to intentional criteria, depending on the level of adequacy of the sample to the research objectives.

\subsection{Instruments}

The first scale (EMG), constructed ad hoc, is composed of 21 items and five ordinal measurement response alternatives from 1 to 5 , where 1 expresses total disagreement with the proposed statement and 5 the maximum degree of agreement. Its design contemplates four dimensions of analysis: Dimension 1 (D1 / 4 items). Inclusion of the gender perspective and women's social experience in the teaching of history. Dimension 2 (D2 / 5 items). Description and analysis of female social roles and social visibility of women in the teaching of history. Dimension 3 (D3 / 6 items) Scientific methodology and historical sources in the construction of historical knowledge. Dimension 4 (D4 / 6 items). Curricular problematization of the teaching of history, social transformation and development of social thinking skills (Table 1).

The second scale (WH) is constructed from 15 brief descriptive definitions of women's history and 20 possible responses attributable to each statement. This scale asked the participating students to connect a feminine proper name with an event or contribution to the history of humanity. Its design contemplates three dimensions of analysis: Dimension 1 (D1 / 4 items). Political leadership. Dimension 2 (D2 / 7 items) Political-cultural leadership. Dimension 3 (D3 / 4 items). Cultural leadership (Table 2). 
Table 1. Epistemology, methodology and gender in taught history (EMG) scale

\begin{tabular}{|c|c|c|}
\hline No. & Dim. & Item \\
\hline 1 & D3 & The historical narrative is the product of the critical application of a systematic process of research. \\
\hline 2 & D2 & The integration of women's social roles into the historical narrative is essential. \\
\hline 3 & D3 & Knowledge of the historical method is fundamental for historians. \\
\hline 4 & D3 & History is the reasonable reconstruction of past events on the comparative basis of available evidence. \\
\hline 5 & D2 & The participation of women in relevant historical events is anecdotal. \\
\hline 6 & D3 & It's absurd for students to study the historical method. \\
\hline 7 & D4 & The teaching of history should focus on the events and/or social problems of the past. \\
\hline 8 & D4 & History constitutes an objective and contrasting narrative set of dates, facts, events and social actors. \\
\hline 9 & D2 & One of the responsibilities of history is to make all social and historical actors visible. \\
\hline 10 & D2 & The description of women's social roles must be added as specific content to the political-institutional narrative or story. \\
\hline 11 & D3 & History is the interpretative reconstruction of past events, based on sometimes contradictory evidence. \\
\hline 12 & D4 & It is unacceptable to address current social issues in history classes. \\
\hline 13 & D4 & Training for the exercise of participatory democracy should be integrated into the curriculum of the history. \\
\hline 14 & D2 & The explanation for the scarce presence of women in history lies in their great invisibility in the available historical sources. \\
\hline 15 & D3 & Any historical narrative or story is useful to approach the past. \\
\hline 16 & D1 & The study of gender relations constitutes a valid category for the analysis and understanding of historical societies. \\
\hline 17 & D4 & Knowledge of history is essential for social transformation. \\
\hline 18 & D1 & Women's historical experience lacks any scientific interest. \\
\hline 19 & D1 & Political and military leaders, mostly men, are the true builders of national history. \\
\hline 20 & D4 & The didactic treatment of social problems favours the development of social and historical thinking skills in students. \\
\hline 21 & D1 & Addressing gender inequality in the teaching of history is not necessary. \\
\hline
\end{tabular}

Table 2. Women in History (WH) scale. Source: [19]

\begin{tabular}{lll}
\hline No. & Dim. & Item \\
\hline 1 & D1 & Fifth queen-pharaoh of the eighteenth dynasty of ancient Egypt. \\
2 & D1 & It expanded and strengthened the Russian empire \\
3 & D2 & Feminist author and wife of Jean Paul Sartre \\
4 & D2 & Muhammad's first wife \\
5 & D2 & Translator for Hernán Cortés, also known as La Malinche. \\
6 & D2 & She wrote Book of de City of Ladies \\
7 & D3 & 12th century Christian mystic and composer \\
8 & D3 & She wrote the Tale of Genji \\
9 & D1 & Prime Minister of Israel \\
10 & D2 & She wrote $A$ vindication of the Rights of Women \\
11 & D3 & Greek poetess \\
12 & D3 & Pioneer in the field of radioactivity \\
13 & D2 & Founder of the Green Belt Movement and Nobel Prize winner \\
14 & D2 & Nun who challenged the clergy in 17th century Mexico \\
15 & D1 & English suffragette and socialist
\end{tabular}

1. Sappho; 2. Joan of Arc; 3. Jingsheng Wei; 4. Lady Murasakid; 5. Hildegard von Bingene; 6. Germaine de Staelf; 7. Marie Curie; 8. Mary Wollstonecrafth; 9. Hatsheputi; 10. Sylvia Pankhurstj; 11. Christine de Pizank; 12. Doña Marina; 13. Sor Juana Inés de la Cruz; 14. Khadijahn; 15. Anastasia Gromykoo; 16. Golda Meir; 17. Catherine the Great; 18. Wangari Maathai; 19. Aisha; 20. Simone de Beauvoir 


\subsection{Design and Procedure}

The research is ascribed to non-experimental research designs of a transversal and exploratory nature $[18,20]$, as its purpose is to begin to understand a set of variables (scales) through its initial exploration at a specific moment. In order to define the concepts that would specify each of the study variables, the construction of the scales was based on the review of the scientific literature and the available empirical background, in particular the studies of Ortega-Sánchez [6], and Ortega-Sánchez and Pagès [11] for the EMG scale. The WH scale consisted of the literal translation into Spanish of the second part of the knowledge survey, applied in Crocco's study [19].

Once the EMG scale was designed, the researchers redefined, in a second research stage, those items that could affect the accuracy of the ratings for containing more than one content or aspect of analysis in the same issue, and specified the dimensions or factors underlying each scale.

Finally, a pilot test was applied to a group of students ( $n$ $=33$ ), enrolled in four Spanish public universities, which share characteristics with the population with which the researchers are expect to work. The objective of this application was to test the measurement instruments, through the operation and evaluation of its construction, writing and understanding of each item by the participants.

\subsection{Data Analysis}

In order to determine its accuracy, stability and consistency, the evaluation of the EMG and WH scales is carried out, as a priority, through the application of measures of reliability and internal consistency of the scales (Cronbach's alpha and McDonald's omega) [21], and the splint-half method, in order to check the degree of correlation between halves of the two scales. Likewise, the linear correlation between each item and the total score of the two scales is measured, for the purpose of identifying those issues that can be reconsidered or eliminated.

In order to explain the theoretical-empirical model of the constructs of the two scales, its validity is studied by means of exploratory factor analysis (EFA) by principal components and varimax rotation with Kaiser normalization, omitting loads lower than . 4 .

Likewise, with the objective of analyzing the agreement between attributes of the variables contemplated in the EMG scale, we calculated the Kendall's coefficient of concordance [22], from the evaluations expressed by 3 independent experts' judges in Didactics of History in a range of 1 to 4 points. For the evaluation of these attributes, the instrument validation format contained in Corral's study [23] is adapted. It consists of four general criteria $\left(\mathrm{C}_{\mathrm{g}}\right)$, applicable to the whole scale, and five specific criteria $\left(\mathrm{C}_{\mathrm{e}}\right)$, applicable to each item: $\mathrm{C}_{\mathrm{g} 1}$. The instrument contains clear and precise instructions for answering the questionnaire; $\mathrm{C}_{\mathrm{g} 2}$. The items allow the objective of the research to be achieved; $\mathrm{C}_{\mathrm{g} 3}$. The items are distributed in a logical and sequential way; $\mathrm{C}_{\mathrm{g} 4}$. The number of items is sufficient to collect the necessary information; $\mathrm{C}_{\mathrm{e} 1}$. Clarity in the wording; $\mathrm{C}_{\mathrm{e} 2}$. Internal coherence; $\mathrm{C}_{\mathrm{e} 3}$. Response induction (bias); $\mathrm{C}_{\mathrm{e} 4}$. Language appropriate to the level of the informant; $\mathrm{C}_{\mathrm{e} 5}$. It measures what it claims to measure.

Finally, in order to analyse the possible dependency relations between the age of the participants and the number of hours of training received on gender, coeducation and education for equality, the degrees of interdependence between variables and scales are analysed.

For data processing and analysis, we use the SPSS v.24 statistical package. In the process of collecting and handling data, participants were guaranteed anonymity of their responses and their subsequent processing.

\section{Results}

\subsection{Analysis of Reliability and Internal Consistency of the EMG Scale}

The reliability analysis of the EMG scale returns a level that is both questionable $(\alpha=.68)$ and adequate $(\omega=.77)$ for the set of variables. The unequal length SpearmanBrown gives a moderate degree of positive correlation between parts of $r=.432$. The reliability of the scale is therefore cautiously confirmed.

The linear item-total correlation coefficients report the existence of correlations greater than .30 in 9 of the 21 items $(r \geq .39)$, and correlations lower than this value in 12 items $(r \leq .27)$. These results indicate the need to review the operation and/or approach of items 1, 2, 4, 5, 7, 8, 9, 10, 11, 14,15 , and 16 . In this sense, the elimination of two of these last items (4 and 7) would favour a significant improvement in the reliability of the scale $(\alpha=.74 ; \omega=.81)$ (Table 3). 
Table 3. Means and variances of scale, item-total correlation coefficients and $\alpha$

\begin{tabular}{|c|c|c|c|c|c|c|c|c|c|}
\hline Item & $M$ & Var. & CI-T & $\alpha$ & Item & $M$ & Var. & CI-T & $\alpha$ \\
\hline 1/ D3 & 77,60 & 61,62 & ,08 & ,68 & $12 / \mathrm{D} 4$ & 76,33 & 53,95 & ,61 & ,63 \\
\hline 2/D2 & 76,10 & 60,92 &, 27 & ,67 & $13 / \mathrm{D} 4$ & 76,53 & 56,53 & ,40 & ,65 \\
\hline 3/ D3 & 76,30 & 57,59 &, 53 & ,65 & 14/ D2 & 78,23 & 60,04 & ,13 & ,68 \\
\hline 4/ D3 & 77,06 & 63,51 &,- 04 &, 70 & 15/ D3 & 78,20 & 58,71 & ,18 & ,68 \\
\hline $5 / \mathrm{D} 2$ & 77,13 & 59,29 & ,09 & ,69 & 16/D1 & 76,46 & 60,32 &, 25 & 67 \\
\hline 6/ D3 & 76,60 & 55,62 & ,39 & ,65 & $17 / \mathrm{D} 4$ & 76,03 & 58,37 &, 47 & ,65 \\
\hline 7/ D4 & 77,90 & 68,16 &,- 27 &, 73 & 18/ D1 & 76,23 & 52,87 & ,63 & ,62 \\
\hline 8/ D4 & 77,76 & 63,15 &, 01 & ,69 & 19/D1 & 76,73 & 51,44 & ,65 & ,62 \\
\hline 9/ D2 & 76,50 & 60,94 & ,19 & ,67 & $20 / \mathrm{D} 4$ & 76,23 & 59,42 & ,43 & ,66 \\
\hline $10 / \mathrm{D} 2$ & 76,60 & 59,69 & ,21 & ,67 & $21 / \mathrm{D} 1$ & 76,33 & 52,50 & ,62 & ,62 \\
\hline 11/ D3 & 77,10 & 63,88 &,- 05 & ,69 & & & & & \\
\hline
\end{tabular}

CI-T: Item-total correlation; $\alpha=$ Cronbach's alpha (deleted element); $M=$ average of scale (deleted element); Var. = variance of scale (deleted element)

\subsection{Validity Analysis of the EMG Scale}

\subsubsection{Content Validity}

The results of the validity analysis show the concordance and homogeneity among the answers expressed by the expert judges. The homogeneity of the responses in the assessments of each attribute is confirmed, in fact, with a high index of significant concordance $\left(\mathrm{w}_{\mathrm{t}}\right)$ between the ranges assigned by the expert judges (Table 4).

Table 4. Values and significance levels of the Kendall concordance coefficient W by judges. EMG scale

\begin{tabular}{ccccccc}
\hline$C_{\mathrm{g}(1,2,3,4)}$ & $C_{\mathrm{e} 1}$ & $C_{\mathrm{e} 2}$ & $C_{\mathrm{e} 3}$ & $C_{\mathrm{e} 4}$ & $C_{\mathrm{e} 5}$ & $W_{\mathrm{t}}$ \\
\hline $1^{*}$ &, $887^{* *}$ &, $886^{* *}$ &, $733^{*}$ &, $733^{*}$ &, $847^{* *}$ \\
\hline
\end{tabular}

${ }^{*} p \leq .05,{ }^{* *} p \leq .01$

These values are based, for the most part, on satisfactory scores of 3 and 4 points for both the general criteria $\left(M_{e} \geq 3\right.$, SD $=.000)$ and the specific criteria contained in the validation instrument. However, the unfavourable assessments of the specific criteria 1 (clarity of wording), 2 (internal consistency) and 5 (accuracy) in the items 4 and 7 are noteworthy, as confirmed by the reliability analysis (Table 5 ). 
Table 5. Median and standard deviation per item (expert judgement) EMG scale.

\begin{tabular}{|c|c|c|c|c|c|c|c|c|c|c|}
\hline Item & $M_{e(1)}$ & $D T_{(1)}$ & $M_{e(2)}$ & $D T_{(2)}$ & $M_{e(3)}$ & $D T_{(3)}$ & $M_{e(4)}$ & $D T_{(4)}$ & $M_{e(5)}$ & $D T_{(5)}$ \\
\hline 1 & 3 &, 000 & 3 &, 000 & 3 &, 000 & 3 &, 000 & 4 & ,000 \\
\hline 2 & 4 &, 000 & 4 & ,000 & 3 & ,577 & 3 & ,577 & 3 & ,577 \\
\hline 3 & 3 & ,577 & 4 & ,577 & 4 &, 000 & 4 & ,577 & 4 & ,577 \\
\hline 4 & 2 &, 000 & 2 & ,000 & 3 & ,000 & 3 & ,577 & 2 & ,000 \\
\hline 5 & 3 & ,000 & 3 & ,000 & 3 & ,000 & 3 & ,000 & 3 &, 000 \\
\hline 6 & 3 &, 000 & 3 &, 000 & 3 &, 000 & 3 & ,000 & 3 &, 000 \\
\hline 7 & 2 &, 000 & 2 & ,000 & 4 & ,577 & 4 & ,577 & 2 & ,000 \\
\hline 8 & 3 & ,000 & 3 & ,000 & 3 &, 000 & 3 & ,000 & 3 & ,000 \\
\hline 9 & 3 & ,000 & 3 & ,000 & 3 & ,000 & 3 & ,000 & 3 & ,000 \\
\hline 10 & 3 &, 000 & 3 &, 000 & 3 & ,000 & 3 &, 000 & 4 & ,577 \\
\hline 11 & 4 & ,000 & 4 & ,577 & 4 & ,577 & 4 & ,000 & 2 & ,000 \\
\hline 12 & 3 &, 000 & 3 & ,000 & 3 & ,000 & 3 &, 000 & 2 &, 000 \\
\hline 13 & 2 &, 000 & 3 & ,000 & 3 & ,000 & 3 & ,000 & 3 & ,000 \\
\hline 14 & 3 &, 000 & 3 &, 000 & 3 &, 000 & 3 & ,000 & 3 &, 000 \\
\hline 15 & 3 & ,000 & 3 & ,000 & 3 & ,000 & 3 &, 000 & 3 & ,000 \\
\hline 16 & 3 & ,000 & 3 & ,000 & 4 & ,577 & 4 & ,577 & 4 & ,000 \\
\hline 17 & 4 &, 577 & 4 &, 000 & 4 & ,000 & 4 & ,000 & 4 & ,577 \\
\hline 18 & 3 & ,000 & 3 & ,000 & 3 & ,000 & 3 & ,000 & 4 & ,577 \\
\hline 19 & 3 &, 000 & 3 & ,577 & 3 &, 000 & 4 &, 000 & 4 &, 000 \\
\hline 20 & 3 &, 577 & 3 &, 000 & 3 & ,000 & 4 & ,000 & 3 &, 000 \\
\hline 21 & 3 & ,000 & 3 &, 000 & 3 & ,577 & 3 &, 000 & 3 & ,577 \\
\hline
\end{tabular}

\subsubsection{Construct Validity}

In order to know the possibilities of factorization, we apply, prior to the analysis of the construct validity, the Bartlett sphericity test and we calculate the sample adequacy measurement index of Kaiser, Meyer and Olkin $(\mathrm{KMO})$. The results obtained in the sphericity test $\chi^{2}=$ $365,103 ; \mathrm{gl} .=210, p=.000)$ indicate an optimal fit of the model, while the value reached in the KMO test (.457) casts doubt on the suitability of the matrix to be factored. However, the analysis returns a factorial solution composed of six factors very close to the dimensions contemplated in the scale design, which help to explain its coherence and latent structure. These factors explain $73.48 \%$ of the total variance, a level considered satisfactory (Table $6)$.

The first factor (6 items) measures the representations related to the inclusion of gender inequalities and the integration of women's social experience in the history teaching, and the valuation of male leadership in the construction of national historical narratives. It also includes the function of knowledge of history in the processes of social transformation, the assessment of the curricular inclusion of social problems and its usefulness in the development of social thinking skills.
Table 6. Rotated component matrix. Original EMG scale

\begin{tabular}{|c|c|c|c|c|c|c|}
\hline \multirow[b]{2}{*}{ Item } & \multicolumn{6}{|c|}{ Component } \\
\hline & 1 & 2 & 3 & 4 & 5 & 6 \\
\hline 21 & ,943 & & & & & \\
\hline 12 & ,869 & & & & & \\
\hline 18 & ,820 & & & & & \\
\hline 20 & ,709 & & & & & \\
\hline 17 & ,703 & & & & & \\
\hline 19 & ,668 & & & & , 480 & \\
\hline 10 & & ,777 & & & & \\
\hline 2 & & ,765 & & & & \\
\hline 9 & &, 745 & & & & \\
\hline 13 & & ,699 & & & & \\
\hline 15 & & ,581 &,- 473 & & ,425 & \\
\hline 4 & & &, 829 & & & \\
\hline 1 & & & ,815 & & & \\
\hline 3 & ,425 & ,439 & ,598 & & & \\
\hline 8 & & & &, 756 & & \\
\hline 11 & & & &,- 729 & & \\
\hline 7 & & & &, 724 & & \\
\hline 14 & & & & & ,725 & \\
\hline 5 & & & &,- 451 & ,650 & \\
\hline 16 & & & & & & ,862 \\
\hline 6 & & & & & & ,610 \\
\hline
\end{tabular}


The second factor (5 items) incorporates the need to integrate women's social roles in the traditional historical narrative, the visibility of women as social and historical agents, training for the exercise of a plural and participatory democracy, and the validity of available narratives for approaching the historical past.

The third factor obtained ( 3 items) informs about the scientific nature of the historical discipline, the knowledge of the historical method and the management of sources for the construction of social knowledge.

Factor 4 (3 items) includes aspects related to the pseudo-objectivity of the historical discipline, with its unidirectional focus on the social events and/or problems of the past, and with its interpretative character on possibly contradictory evidence.

Factor 5 ( 2 items) includes the variables related to women's participation in the construction of the historical narrative and to their supposed invisibility in the available sources.

Finally, factor 6 ( 2 items) includes the last two variables on the incorporation of the historical method in the history teaching and learning, and of gender relations as a valid category for the analysis and understanding of historical societies.

The elimination of items 4 and 7, in spite of improving the scale factorization indicators $\left(.472 ; \chi^{2}=312,290 ; \mathrm{gl} .=\right.$ $171, p=.000)$, the resulting factors $(74.75 \%$ of the total variance explained) do not return significant changes in its latent structure. It is therefore decided to rethink it and not to eliminate it (Table 7).
Table 7. Rotated component matrix. Revised EMG scale

\begin{tabular}{|c|c|c|c|c|c|c|}
\hline \multirow[b]{2}{*}{ Item } & \multicolumn{6}{|c|}{ Component } \\
\hline & 1 & 2 & 3 & 4 & 5 & 6 \\
\hline 21 & ,947 & & & & & \\
\hline 12 & ,877 & & & & & \\
\hline 18 & ,829 & & & & & \\
\hline 17 & ,697 & & & & & \\
\hline 20 & ,695 & & & & & \\
\hline 19 & ,643 & & ,481 & & & \\
\hline 10 & & ,818 & & & & \\
\hline 2 & & ,788 & & & & \\
\hline 9 & & ,757 & & & & \\
\hline 13 & & ,671 & & & & \\
\hline 15 & & ,534 & , 459 & &,- 467 & \\
\hline 5 & & & ,681 &, 447 & & \\
\hline 14 & & & 680 & & & \\
\hline 11 & & & &, 770 & & \\
\hline 8 & & & &,- 733 & & \\
\hline 1 & & & & &, 849 & \\
\hline 3 & & , 469 & & &, 590 & \\
\hline 16 & & & & & &, 820 \\
\hline 6 & & & & & & ,621 \\
\hline
\end{tabular}

\subsection{Analysis of Reliability and Internal Consistency of the WH Scale}

The reliability analysis of the WH scale returns a satisfactory level for the set of variables $(\alpha=.83 ; \omega=.85)$. Similarly, the unequal length Spearman-Brown shows a high degree of positive correlation between parts of $r=$. 705 , confirming the reliability of the scale.

Table 8. Means and variances of scale, item-total correlation coefficients and $\alpha$

\begin{tabular}{cccccccccc}
\hline Item & $M$ & Var. & CI-T & $\alpha$ & Item & $M$ & Var. & CI-T & $\alpha$ \\
\hline 1/ D1 & 5,56 & 12,77 &, 39 &, 83 & $9 / \mathrm{D} 1$ & 5,78 & 11,59 &, 73 &, 80 \\
2/ D1 & 5,68 & 11,57 &, 73 &, 80 & $10 / \mathrm{D} 2$ & 5,96 & 12,03 &, 70 &, 81 \\
3/ D2 & 5,65 & 12,55 &, 43 &, 82 & $11 / \mathrm{D} 3$ & 5,50 & 12,51 &, 50 &, 82 \\
4/ D2 & 6,09 & 14,21 &, 01 &, 84 & $12 / \mathrm{D} 3$ & 5,46 & 12,64 &, 49 &, 82 \\
5/ D2 & 5,75 & 12,19 &, 54 &, 82 & $13 / \mathrm{D} 2$ & 5,90 & 12,53 &, 48 &, 82 \\
6/ D2 & 5,96 & 13,38 &, 24 &, 83 & $14 / \mathrm{D} 2$ & 5,81 & 12,86 &, 35 &, 83 \\
7/ D3 & 6,12 & 14,43 &,- 06 &, 84 & $15 / \mathrm{D} 1$ & 5,84 & 11,62 &, 74 &, 80 \\
8/ D3 & 5,93 & 13,02 &, 34 &, 83 & & & & & \\
\hline
\end{tabular}

CI-T: Item-total correlation; $\alpha=$ Cronbach's alpha (deleted element); $M=$ average of scale (deleted element); Var. = variance of scale (deleted element) 
The linear item-total correlation coefficients report the existence of correlations greater than .30 in 13 of the 15 items $(r \geq .344)$, and of correlations lower than this value in 2 items $(r=.016 ; r=-.068)$. Although these results indicate the convenience of reviewing the operability of items 4 and 7, it was decided to maintain it in the construction of the scale, since its elimination would not lead to a substantial improvement in the level of reliability of the instrument $(\alpha=.86 ; \omega=.91)$ (Table 8$)$.

\subsection{Validity Analysis of the WH Scale}

After applying Bartlett sphericity test and calculating the sample adequacy measurement index KMO, the results obtained show the adequacy of the model $\left(\chi^{2}=239,321\right.$; gl. $=105, p=.000)$ and the relevance of the matrix to be factored (.667). The EFA returns a factorial solution composed of five factors that approximate the dimensions contemplated in the scale design. These factors explain $75.13 \%$ of the total variance (Table 9).

Table 9. Rotated component matrix. WH scale

\begin{tabular}{|c|c|c|c|c|c|}
\hline & \multicolumn{5}{|c|}{ Component } \\
\hline Item & 1 & 2 & 3 & 4 & 5 \\
\hline 9 & ,927 & & & & \\
\hline 15 & ,910 & & & & \\
\hline 2 &, 767 & ,408 & & & \\
\hline 13 &, 735 & & & & \\
\hline 10 & 683, & & ,411 & & \\
\hline 12 & & ,859 & & & \\
\hline 11 & ,432 & ,664 & & & \\
\hline 3 & & ,659 & ,473 & & \\
\hline 5 & & ,615 & & & \\
\hline 6 & & &, 883 & & \\
\hline 8 & & & ,862 & & \\
\hline 7 & & & & ,872 & \\
\hline 4 & & & ,412 & ,583 & \\
\hline 1 & & & & & ,768 \\
\hline 14 & & & & &,- 570 \\
\hline
\end{tabular}

\subsection{Correlations between Scales and Variables}

An adequate interdependence between the EMG and WH scales is evident for its joint application, reaching a positive degree of moderate correlation between the $\mathrm{WH}$ scale and the original EMG scale $(\rho=.447, p=.015)$, and between the WH scale and the revised EMG scale $(\rho=.466$, $p=$.011) (Table 10).
Table 10. Spearman correlations between age and training hours variables, and EMG and WH scales

\begin{tabular}{lcccccc}
\hline & $\mathrm{E}$ & $\mathrm{F} 1$ & $\mathrm{~F} 2$ & $\mathrm{E}_{\mathrm{a}}$ & $\mathrm{E}_{\mathrm{b}}$ & $\mathrm{E} 2$ \\
\hline $\mathrm{E}$ & 1 & & & & & \\
$\mathrm{~F} 1$ &, $569^{*}$ & 1 & & & & \\
$\mathrm{~F} 2$ &,- 309 &,- 047 & 1 & & & \\
$\mathrm{E} 1 \mathrm{a}$ &, 352 &, $747^{* *}$ &,- 357 & 1 & & \\
$\mathrm{E} 1 \mathrm{~b}$ &, 325 &, $794^{* *}$ &,- 337 &, $981^{* *}$ & 1 & \\
$\mathrm{E} 2$ &, $565^{* *}$ &, 287 &,- 308 &, $447^{*}$ &, $466^{*}$ & 1 \\
\hline${ }^{*} p \leq .05,{ }^{* *} p \leq .01$ & & & & &
\end{tabular}

\section{E: Age}

F1: Number of hours of gender training received

F2: Number of hours of training on coeducation and education for gender equality in the classroom received

E1 $1_{\mathrm{a}}$ : Original scale of Epistemology, Methodology, and Gender in the Teaching of History (EMG)

$\mathrm{E} 1_{\mathrm{b}}$ : Revised scale of Epistemology, methodology, and gender in the teaching of history (EMG)

E2: Original scale Women in History (WH)

A moderate degree of correlation is also confirmed between the age of the participants and the number of hours of gender training received $(\rho=.569, p=.017)$, and between the age variable and the WH knowledge scale $(\rho$ $=.565, p=.001)$. On the contrary, this same age variable does not seem to influence the values expressed in the EMG scale $(\rho=.352, p=.057 ; \rho=.325, p=.080)$.

Likewise, the hours of gender training received show high levels of correlation with the two EMG scales, especially with its revised version $(\rho=.747, p=.001 ; \rho$ $=.794, p=.000$ ). No significant correlations are recorded among the number of hours of specific training in coeducation and education for gender equality and the age of the informants $(\rho=-.309, p=.080)$, and the EMG scales $(\rho=-.357, p=.053 ; \rho=-.337, \mathrm{p}=.069)$ and $\mathrm{WH}(\rho$ $=-.308, p=.087)$.

\section{Discussion and Conclusions}

The results obtained confirm the viability of the EMG and WH scales for the study of the social representations of future teachers on the inclusion of the gender perspective and the visibility of women in the history classroom. Likewise, its functionality for its joint application is evidenced and the hours of gender training received are identified as conditioning factors in the construction of the social representations of the students. The age variable, on the other hand, seems to influence students' knowledge of women's history.

The inclusion of the gender perspective and the educational treatment of equality between women and men requires teacher training capable of promoting conscious and committed positions to be active agents in the transformation of social patterns [24]. It is therefore 
necessary to treat critical-reflective skills and, in particular, gender skills in teaching programs [9]. From this perspective, approaching the principles and sources with which the social representations of future teachers are constructed involves analyzing the place that students give to women, their historical experience and their contributions to the construction of historical knowledge. These programs must offer future teachers the skills necessary to make past and present social reality more complex, analyze the different constructions of gender in time and space, deal with situations with equity [25], and address it as a system constituted and built by men and women with functions and possibilities for social and personal development that are not necessarily identical, intimately linked to a previous historical trajectory and to the very dynamics of gender relations [1].

As evidenced by the studies of Díez [25] and Ortega-Sánchez, Carcedo de Andrés, and Blanco [26], there are few end-of-degree/master projects in the field of social sciences that include the gender perspective in its end-purposes. If a gender discourse is recognized, it continues to appear linked to a problem that is linked to women, which evidences unequal positions [25]. This is also a reality in the educational projects of the social sciences [27].

In this line, the results obtained in the research of Bartual, Carbonell, Carreras, Colomé, and Turmo [28], in the area of history and economics teaching, show that the specific treatment of content on gender in higher education favors the positioning and awareness of students about inequality and social justice. It continues to be necessary, therefore, the educational transposition of the historical research, and to incorporate the bases of new historiographical currents, criticism and reflection in historical education and in the contexts of teacher training [29].

According to Crocco's study [19], more than half of a sample of 60 new and experienced social science teachers showed that they knew less than $50 \%$ of the names of the women proposed in the questionnaire and of their contributions to world history. The explanation for these results could lie in the recognition of the tensions between the aspiration to identify and achieve a history of women and gender as a specific area of research, and the aspiration that women and gender be treated as themes/categories of analysis that are constitutive of all historical research [30] and of social science teacher training plans.

Recent research results confirm the permanence of hegemonic, non-inclusive curricular approaches and the invisibility of women in the history taught [16, 31-34]. This reality drives the urgency of specific and transversal teacher training on gender, capable of overcoming an androcentric approach still recognizable in teachers' teaching practices, in their decision-making on content, in the definition of interpersonal relations and in the way tasks are assigned in the school context. In this sense, the EMG and WH scales for diagnostic assessment offered are intended to serve as scientifically rigorous instruments for analysis and training intervention on knowledge about the place of women in the taught history, the way in which gender inequality is recognized as a social problem by students and for the mobilization of their social representations. This evaluation should therefore be used to reflect on university training programs, and to promote a gender perspective and global and inclusive citizenship in the teaching of history and social sciences at all levels of education [35].

Despite the legislative and normative-curricular advances of recent decades in Spain, education in gender equality and the implementation of teaching programs in and for equality continue to require initial training in history and social sciences committed to social justice [31]. This commitment would also have to be defined within the framework of education for democratic citizenship capable of revealing the provisional nature and constructive mechanisms of social knowledge [5,6,32]. In this sense, investigating the social representations of teachers in training, using instruments such as those studied in this research, is the first step towards reflecting on university curricula and innovating, reflecting on and improving teaching practices, as well as adopting critical perspectives aimed at social transformation.

\section{Acknowledgments}

The study was approved by the research project EDU2016 - 80145 - P (Ministry of Economy and Business of Spain), and by the Research Group of the University of Burgos of Didactics of History and Social Sciences (DHISO).

\section{REFERENCES}

[1] Fernández, A. (2004a). Las mujeres como sujeto histórico: género y enseñanza de la historia. Didáctica de las Ciencias Experimentales y Sociales, 18, pp. 5-24.

[2] Marolla, J. (2016). ¿Cómo podemos construir identidades para las mujeres desde la invisibilidad? Reflexiones en torno a las concepciones del profesorado chileno sobre la inclusión y ausencias de la Historia de las Mujeres. In García, Carmen Rosa, Aurora Arroyo and Beatriz Andreu (eds.). Deconstruir la alteridad desde la didáctica de las ciencias sociales: educar para una ciudadanía global. Las Palmas: Universidad de Las Palmas de Gran Canaria-AUPDCS, pp. 425- 432.

[3] Fernández, A. (2004b). El género como categoría de análisis en la enseñanza de las Ciencias Sociales. In Vera, Isabel and David Pérez (eds.). Formación de la ciudadanía: las Tics y los nuevos problemas. Alicante: AUPDCS, pp. 565-683.

[4] Scott, J. W. (1986). El género: una categoría útil para el análisis histórico, American Historical Review, 91, pp. 
1053-1075.

[5] García, A., De la Cruz, A. (2017). Coeducación en la formación inicial del profesorado: una estrategia de lucha contra las desigualdades de género. In Martínez, Ramón, Roberto García-Morís and Carmen Rosa García (eds.). Investigación en Didáctica de las Ciencias Sociales. Retos, preguntas y líneas de investigación. Córdoba: Universidad de Córdoba-AUPDCS, pp. 133-142.

[6] Ortega-Sánchez, D. (2017). Las mujeres en la enseñanza de la Historia y de las Ciencias Sociales. Estudio de caso en formación inicial de maestros y maestras de Educación Primaria, Universitat Autònoma de Barcelona, Barcelona. Online

fromhttp://www.tdx.cat/handle/10803/457981

[7] Ortega-Sánchez, D. Pérez, C. (2015). Las mujeres en los libros de texto de Ciencias Sociales de $1^{\circ}$ de ESO. In Hernández, Ana María, Carmen Rosa García and Juan Luis de la Montaña (eds.). Una enseñanza de las Ciencias Sociales para el futuro: recursos para trabajar la invisibilidad de personas, lugares y temáticas. Cáceres: Universidad de Extremadura-AUPDCS, pp. 943-951.

[8] Gómez-Carrasco, C., Gallego-Herrera, S. (2016). La pervivencia de estereotipos de género en la enseñanza de la historia. Un estudio a través de libros de texto y las percepciones del alumnado de educación secundaria en España. Revista Electrónica Educare, 20(3), pp. 1-28. doi: 10.15359/ree.20-3.1

[9] Ortega-Sánchez, D., Pagès, J. (2018). Género y formación del profesorado: análisis de las Guías Docentes del área de Didáctica de las Ciencias Sociales, Contextos Educativos. Revista de Educación, 21, pp. 53-66.

[10] Ortega-Sánchez, D., Pagès, J. (2017). Literacidad crítica, invisibilidad social $\mathrm{y}$ género en la formación del profesorado de Educación Primaria, REIDICS. Revista de Investigación en Didáctica de las Ciencias Sociales, 1, pp. 102-117. doi: 10.17398/2531-0968.01.102

[11] Ortega-Sánchez, D., Pagès, J. (2016). Deconstruyendo la alteridad femenina en la enseñanza de la historia escolar: representaciones sociales del profesorado de Educación Primaria en formación. In García, Carmen Rosa, Aurora Arroyo and Beatriz Andreu (eds.). Deconstruir la alteridad desde la didáctica de las ciencias sociales: educar para una ciudadanía global. Las Palmas: Universidad de Las Palmas de Gran Canaria-AUPDCS, pp. 184-193.

[12] Marolla, J. (2015). ¿Qué sabemos sobre la enseñanza de la Historia de las mujeres? Algunas reflexiones sobre los discursos del profesorado chileno. In Hernández, Ana María, Carmen Rosa García and Juan Luis de la Montaña (eds.). Una enseñanza de las Ciencias Sociales para el futuro: recursos para trabajar la invisibilidad de personas, lugares y temáticas. Cáceres: Universidad de Extremadura-AUPDCS, pp. 889-897.

[13] Crocco, M. S. (2010). Using literature to teach about outhers: the case of Shabanu. In Parker, Walter C. (ed.). Social studies today: research and practice. New York: Routledge, pp. 175-182.

[14] Bickmore, K. (2008). Social justice and the social studies. In Levstik. Linda S. and Cynthia A. Tyson (eds.). Handbook of Research in Social Studies Education. New York: Roudledge, pp. 155-171.
[15] Crocco, M. S. (2008). Gender and sexuality in the social studies. In Levstik. Linda S. and Cynthia A. Tyson (eds.). Handbook of Research in Social Studies Education. New York: Roudledge, pp. 172- 196.

[16] Ortega-Sánchez, D. (2019). Teaching Gender in the History Classroom: An Investigation into the Initial Training of Primary Education Teachers, Educ. Sci., 9(2), 114. doi: 10.3390/educsci9020114

[17] Fernández, A. (2015). Género y enseñanza de la Historia. In Domínguez, María Almudena and Rosa María Marina (eds.). Género y enseñanza de la Historia: silencios y ausencias en la construcción del pasado. Madrid: Sílex, pp. 29-55.

[18] Hernández, R., Fernández, C., Baptista, M. del P. (2010). Metodología de la investigación, McGraw-Hill, México, D.F.

[19] Crocco, M. S. (2011). Teaching about women in World History, The Social Studies, 102(1), pp. 18-24. doi: 10.108 0/00377996.2011.532731

[20] Albert, M. J. (2007). La investigación educativa: claves teóricas, McGraw-Hill, Madrid.

[21] Oviedo, H. C., Campo-Arias, A. (2005). Aproximación al uso del coeficiente alfa de Cronbach, Rev.colomb.psiquiatr., 34(4), pp. 572-780.

[22] Field, A. (2014). Kendall's Coefficient of Concordance. Wiley StatsRef: Statistics Reference Online. doi: 10.1002/ 9781118445112.stat06537

[23] Corral, Y. (2009). Validez y confiabilidad de los instrumentos de investigación para la recolección de datos, Revista Ciencias de la Educación, 19(33), pp. 228-247.

[24] Rebollo, M. Á., García, R., Piedra, J., Vega, L. (2011). Diagnóstico de la cultura de género en educación: actitudes del profesorado hacia la igualdad, Revista de Educación, 355, pp. 521-546.

[25] Díez, M. C. (2017). Con y para la sociedad. Análisis del discurso de género de alumnado en Trabajos Fin de Grado/Máster de Ciencias Sociales. In Martínez, Ramón, Roberto García-Morís and Carmen Rosa García (eds.). Investigación en Didáctica de las Ciencias Sociales. Retos, preguntas y líneas de investigación. Córdoba: Universidad de Córdoba-AUPDCS, pp. 102-114.

[26] Ortega-Sánchez, D., Carcedo de Andrés, B. P., Blanco, P. (2018). El Trabajo Fin de Grado en Didáctica de las Ciencias Sociales: análisis y balance de líneas, materias y temáticas, REIDICS. Revista de Investigación en Didáctica de las Ciencias Sociales, 3, pp. 35-51. doi: 10.17398/2531-0968.03.35

[27] Díez, M. del C. (2014) Indicadores para el seguimiento y evaluación de la perspectiva de género en proyectos educativos de ciencias sociales. In Pagés, Joan and Antoni (eds.). Una mirada al pasado y un proyecto de futuro: investigación e innovación en didáctica de las ciencias sociales. Barcelona: Universitat Autónoma de Barcelona-AUPDCS, pp. 45-52

[28] Bartual, M. T., Carbonell, M., Carreras, A., Colomé, J., Turmo, J. (2018). La perspectiva de género en la docencia universitaria de Economía e Historia, Revista d'Innovació 
Docent Universitària, 10, pp. 92-101.

[29] García, A. (2015). Mujeres visibles e invisibles en la enseñanza de la Historia en la Educación Primaria: cambios y pervivencias al amparo de la LOMCE. In Hernández, Ana María, Carmen Rosa García and Juan Luis de la Montaña (eds.). Una enseñanza de las Ciencias Sociales para el futuro: recursos para trabajar la invisibilidad de personas, lugares y temáticas. Cáceres: Universidad de Extremadura-AUPDCS, pp. 163-173.

[30] Groot, J. (2018). Women's History in many places: reflections on plurality, diversity and polyversality, Women's History Review, 27(1), pp. 109-119. doi: $10.1080 / 09612025.2016 .1250528$

[31] Ortega-Sánchez, D., Pagès, J. (2020). The End-Purpose of Teaching History and the Curricular Inclusion of Social Problems from the Perspective of Primary Education Trainee Teachers. Soc. Sci., 9(2), 9. doi: 10.3390/socsci90 20009

[32] Felices de la Fuente, M. del M., Moreno, C., Jiménez, M. D. (2016). Ciudadanía global igualitaria y formación del profesorado. In García, Carmen Rosa, Aurora Arroyo and Beatriz Andreu (eds.). Deconstruir la alteridad desde la didáctica de las ciencias sociales: educar para una ciudadanía global. Las Palmas: Universidad de Las Palmas de Gran Canaria-AUPDCS, pp. 236-245.

[33] Ortega-Sánchez, D., Marolla, J., Heras, D. (2020). Invisibilidades sociales, identidades de género y competencia narrativa en los discursos históricos del alumnado de Educación Primaria. In Díez, Enrique Javier and Juan Ramón Rodríguez (dirs.). Educación para el Bien Común. Hacia una práctica crítica, inclusiva y comprometida socialmente. Barcelona: Octaedro, pp. 89-103.

[34] Ortega-Sánchez, D., Pagès, J. (2019). La inclusión de la perspectiva de género en la enseñanza de la historia y de las ciencias sociales: análisis de los discursos y expectativas docentes de los y las estudiantes de Magisterio. In Ballbé, M., Neus González-Monfort, Antoni Satisteban (eds.). Quin professorat, quina ciutadania, quin futur? Els reptes de l'ensenyament de les ciències socials, la geografia i la història. Barcelona: Universitat Autònoma de Barcelona, pp. 183-190.

[35] Ortega-Sánchez, D., Olmos, R. (2019). Historia enseñada y género: influencia de las variables sociodemográficas, nivel educativo e itinerario curricular en las creencias epistemológicas y metodológicas del alumnado de Educación Secundaria, Clio. History and history teaching, 45. Available on https://bit.ly/34M6Vnr 